\title{
EVALUATION OF CERTAIN KIDNEY BEAN, PHASEOLUS VULGARIS L. VARIETIES FOR THEIR INFESTATION WITH \\ TETRANYCHUS CUCURBITACEARUM (SAYED) AND BEMISIA TABACI (GENN.) UNDER FIELD CONDITIONS OF KAFR EL-SHEIHK
}

\author{
MAGOUZ, R.I.E., S. A. A. KASSEM AND JEHAN B. EL-NAGGAR
}

Plant Protection Research Institute, ARC, Dokki, Giza, Egypt

(Manuscript received 9 January 2011)

\begin{abstract}
Field experiments were carried out at Sakha Agric. Res. Station Farm, Kafr El-Sheikh to evaluate certain kidney bean varieties (Pronco, French bean and Polesta) and two breeding lines( FI hybrid and R1655) of bean, Phaseolus vulgaris L for their relative susceptibility to the spider mite, Tetranychus cucurbitacearum (Sayed) and the white fly, Bemisia tabaci (Genn.) on three varieties. during two successive seasons, 2008 and 2009 .

Obtained data showed that $T$. cucurbitacearum recorded the highest numbers during the third week of July in the first season, while B. tabaci appeared its maximum in the fourth week of June. Meanwhile, in the second season the two pests recorded the highest number in the fourth week of July. The numbers of $T$. cucurbitacearum were higher than $B$. tabaci during the two study seasons. The population density of $T$. cucurbitacearum was higher in the first season than in the second one, while $B$. tabaci showed the reverse.

Based on the mean number of the two study seasons, variety Polesta harbored significantly the highest population of $T$. cucurbitacearum followed by French bean and the breeding line Fl hybrid, while R1655 was the lowest infested. The highest infestation with $B$. tabaci occurred on French bean while, Pronco and R1655 were the least infested.

Regarding to the susceptibility degree to the two pests, varieties Polesta, French bean and breeding line FI hyprid appeared susceptible. The variety Pronco appeared as low resistant and breeding line R1655 appeared as moderate resistant.

Thus, the gained results should be taken into account in planning programs of integrated pest management in the bean fields.
\end{abstract}

\section{INTRODUCTION}

The kindy bean, Phaseolus vulgaris L. is one of the most important vegetables in many parts of the world as it contains a complete protein compared with the other vegetables. In Egypt, this crop has been subjected to attack by several pests, among which are the spider mite, Tetranychus 
cucurbitacearum (Sayed) and the white fly, Bemisia tabaci (Genn.). These pests caused severe damage to the plants by feeding on the plant sap in addition to plant viruses transmission (Helaly et. a|., 1983, Wahba et. al., 1986, Metwally, 1989, Metwally and Mahgoub, 1991 and Pena Rojas et. al., 1992).

In general, the chemical control of these pests creates several problems i.e., environmental pollution, destruction of beneficial insects and pest resistance to many pesticides (John et. al., 1986). Therefore, it is necessary to select the tolerant or resistant varieties as one of the simplest and useful tactics in the integrated pest management programs (Dent, 1991). However, plant resistance to insects is generally derived from certain biochemical and /or the metabolism of insects influencing the relative degrees of damage caused by these insects (Metcalf and Luckmann, 1975).

So, the present work was carried out to study the population fluctuation of the spider mite, T. cucurbitacearum and the white fly, B. tabaci on three varieties and two breeding lines of bean during two successive seasons, 2008 and 2009 at Kafr El-Sheikh governorate.

\section{MATERIALS AND METHODS}

Field experiments were carried out at Sakha Agric. Res. Station Farm, Kafr El-Sheikh Governorate during the two successive bean growing seasons, 2008 and 2009. Three bean varieties (Pronco, French bean and Polesta) and two breeding lines ( FI hybrid and R1655 ) were supplied by National Legumes Research Program at Sakha Agric. Res. Station. For each season, the experimental area was divided into 20 plots, each of $42 \mathrm{~m}^{2}$. The tested varieties and the breeding lines were sown in the first week of May and June during the first and second season, respectively in a complete randomized block design with four replicates for each. The normal agricultural practices were followed without any pesticidal treatments throughout the growing season. Weekly sample of 10 bean leaves was collected at random from each plot when plants were one month old and continued till the end of the growing season. The collected leaves were kept in paper bags and transferred to the laboratory to count the motile stages of spider mite and the immature stages of white fly by the aid of steromicroscope.

Classification of the susceptibility degree of each bean cultivar was determined according to the general mean of number ( $\mathrm{x}$ )of each pest and the standard deviation (SD) as reported by Chiang and Talekar (1980). The variety or the breeding line that had mean number of the pest more than $X+2 S D$ was considered 
highly susceptible (HS), between $X$ and $X+2 S D$, susceptible (S), between $X$ and 11SD, low resistant (LR), between X- 1SD and X-2SD moderately resistant (MR) and less than X-2SD was considered highly resistant (HR).

The obtained data were statistically analyzed using F- test and the mean numbers of the two pests were compared according to Duncans multiple range test (Duncan, 1955).

\section{RESULTS AND DISCUSSION}

\section{1- Population fluctuation of Tetranychus cucurbitacearum (Sayed) and Bemisia tabaci (Genn.) on certain bean varieties and breeding lines during 2008 and 2009 growing seasons}

Data presented in table (1) exhibit the numbers of the spider mite, $T$. cucurbitacearum (motile stages) and the white fly, B. tabaci (nymphs) on three bean varieties (Pronco, French bean and Polesta) and two breeding lines (FI hybrid and R1655) during the growing season of 2008. With regard to the spider mite, the population began to appear with few numbers in the first week of June nearly on all the tested varieties and the breeding lines. Afterwards, the numbers increased sharply recording its maximum in the third week of July with means of 393.0, 770.3, 443.3, 279.5, 389.3 individuals / 10 leaves for Pronco, French bean, Polesta, R1655 and FI hybrid, respectively ( at $26.9 \mathrm{C}^{\circ}$ and $66.5 \% \mathrm{RH}$ ). The level infestation of whitefly, the insect started in very few numbers in the second week of June on the tested varieties and the breeding lines. Then, the population increased gradually till reaching its peak in the fourth week of June by $9.8,15.8$, 12.3, 7.3 and 19.5 nymphs / 10 leaves on Pronco, French bean, Polesta ,R1655 and $\mathrm{FI}$ hybrid, respectively (at $25.0 \mathrm{C}^{\circ}$ and $67.2 \% \mathrm{RH}$ ) and decreased gradually till the end of the season.

During 2009 season, table (2) revealed that the spider mite appeared with a low number in the first week of July for the tested varieties and the breeding lines, while the first infestation with B. tabaci started one week later. After that, the population of the two pests increased recording its maximum in the fourth week of July at $26.3 \mathrm{C}^{\circ}$ and $75.2 \% \mathrm{RH}$. The population then declined gradually till the end of the season. 
1290 EVALUATION OF CERTAIN KIDNEY BEAN, PHASEOLUS VULGARIS L. VARIETIES FOR THEIR INFESTATION WITH TETRANYCHUS CUCURBITACEARUM (SAYED) AND BEMISIA TABACI (GENN.) UNDER FIELD CONDITIONS OF KAFR EL-SHEIHK

Table 1. Mean number of Tetranychus cucurbitacearum (Sayed) and Bemisia tabaci (Genn.)/IO leaves of three bean varieties and two breeding lines during 2008 season.

\begin{tabular}{|c|c|c|c|c|c|c|c|c|c|c|c|c|c|}
\hline \multicolumn{2}{|c|}{ Sampling date } & \multicolumn{5}{|c|}{ T. cucurbitacearum } & \multicolumn{5}{|c|}{ B. tabaci } & \multicolumn{2}{|c|}{$\begin{array}{l}\text { Weather } \\
\text { factors }\end{array}$} \\
\hline Month & week & 1 & 2 & 3 & 4 & 5 & 1 & 2 & 3 & 4 & 5 & Temp. & $\mathrm{RH} \%$ \\
\hline \multirow[t]{4}{*}{ June } & $1 s t$ & 0.0 & 3.0 & 5.8 & 6.3 & 9.3 & 0.0 & 0.0 & 0.0 & 0.0 & 0.0 & 23.8 & 63.8 \\
\hline & $2^{\text {nd }}$ & $\begin{array}{ll}11.3 \\
\end{array}$ & 21.5 & 14.3 & 10.3 & 22.0 & L5 & 7.5 & 0.0 & 0.8 & 3.8 & 24.6 & 62.6 \\
\hline & $3^{\text {td }}$ & 30.5 & 62.8 & 49.3 & 25.0 & 60.0 & 7.0 & 6.5 & 1.5 & 6.5 & 15.3 & 24.6 & 66.9 \\
\hline & $4^{\text {th }}$ & 149.3 & 70.5 & 120.3 & 44.0 & 133.0 & 9.8 & 15.8 & 12.3 & 7.3 & 19.5 & 25.0 & 67.2 \\
\hline \multirow[t]{4}{*}{ July } & $1 s t$ & 138.0 & 95.5 & 135.8 & 60.0 & 103.0 & 1.5 & 9.8 & 2.0 & 5.8 & 4.0 & 26.7 & 70.1 \\
\hline & $2^{\text {nd }}$ & 387.0 & 2103 & 341.5 & 153.5 & 273.0 & 0.5 & 8.3 & L3 & 1.3 & 2.0 & 27.0 & 71.9 \\
\hline & $3^{\text {td }}$ & 393.0 & 770.3 & 443.3 & 279.5 & 389.3 & 15 & 1.8 & 0.5 & 1.5 & 1.0 & 26.9 & 66.5 \\
\hline & $4^{\text {th }}$ & 166.3 & 646.5 & 117.0 & $265-8$ & 248.5 & 0.3 & 3.0 & 0.0 & 1.8 & 0.0 & 25.9 & 70.0 \\
\hline \multicolumn{2}{|c|}{ General mean } & 159.43 & 241.05 & 153.41 & 105.55 & 154.76 & 2.76 & 6.59 & 2.20 & 3.13 & 5.70 & 25.49 & 67.38 \\
\hline
\end{tabular}

1= Pronco $\quad 2=$ French bean $\quad 3=$ Polesta $\quad 4=$ R1655 $5=$ Fl hybrid

\section{2- The relative susceptibility of certain bean varieties and breeding lines to Tetranychus cucurbitacearum (Sayed) and Bemesia tabaci (Genn.)}

Table (3) showed the mean number and the relative susceptibility of three bean varieties and two breeding lines to the spider mite and the white fly during the growing seasons, 2008 and 2009. It was cleared that, the mite individuals was higher than B. tabaci during the two study seasons. Also, the population of $T$. cucurbitacearum was higher on the tested varieties and the breeding lines in the first season than in the second one, while the reverse was obtained for the white fly. This may be due to the effect of climatic factors and / or the abundance of the natural enemies as mentioned by $\operatorname{Kumar}(1984)$ who reported that certain environmental conditions influence fundamental physiological processes of the plant as well as the pest. Thus, a variety that exhibits resistance in one locality or environment may be susceptible in another. Also, Metcalf and Luckmann (1975) reported that certain environmental conditions may alter the physiology of the plant to the extent that it becomes unsuitable as a host for a certain pest. 
Table 2. Mean number of Tetranychus cucurbitacearum (Sayed) and Bemisia tabaci (Genn.) / 10 leaves of three bean varieties and two breeding lines during 2009 season.

\begin{tabular}{|c|c|c|c|c|c|c|c|c|c|c|c|c|c|}
\hline \multicolumn{2}{|c|}{ Sampling date } & \multicolumn{5}{|c|}{ T. cucurbitacearum } & \multicolumn{5}{|c|}{ B. tabaci } & \multicolumn{2}{|c|}{ Wealher factors } \\
\hline Month & week & 1 & 2 & 3 & 4 & 5 & 1 & 2 & 3 & 4 & 5 & Temp. & $\mathrm{RH} \%$ \\
\hline \multirow[t]{4}{*}{ July } & $1 s t$ & 25.8 & 1.8 & 9.0 & 18.5 & 11.0 & 0.0 & 0.0 & 0.0 & 0.0 & 0.0 & 25.2 & 72.2 \\
\hline & $2^{\text {nd }}$ & 48.8 & 7.5 & 21.5 & 37.8 & 23.0 & 0.3 & 2.0 & 0.3 & 2.3 & 1.3 & 25.4 & 71.8 \\
\hline & $3^{\mathrm{d}}$ & 150.0 & III. 8 & 431.0 & 68.3 & 199.5 & 13.3 & 30.0 & 12.5 & 6.0 & 30.8 & 27.0 & 71.5 \\
\hline & $4^{\text {h }}$ & 150.8 & 154.5 & 670.0 & 79.5 & 478.0 & 28.5 & 43.0 & 60.0 & 26.0 & 31.5 & 26.3 & 75.2 \\
\hline \multirow[t]{3}{*}{ Aug. } & 1st & 24.0 & 23.8 & 102.0 & 19.8 & 54.0 & 10.8 & 26.8 & 15.5 & 7.8 & 16.8 & 27.3 & 74.8 \\
\hline & $2^{\text {nd }}$ & 9.8 & 8.0 & 19.3 & 5.3 & 10.8 & 8.0 & 13.5 & 12.5 & 5.8 & 9.3 & 27.4 & 73.8 \\
\hline & $3^{\text {d }}$ & 3.8 & 4.0 & 7.5 & 2.0 & 4.5 & 5.0 & 6.3 & 8.8 & 8.0 & 10.8 & 24.5 & 72.9 \\
\hline \multicolumn{2}{|c|}{ General mean } & 58.96 & 44.46 & 180.04 & 33.00 & 111.54 & 9.39 & 17.36 & 15.64 & 7.96 & 14.32 & 26.16 & 73.17 \\
\hline
\end{tabular}

$$
\text { 1= Pronco } 2 \text { = French bean } \quad 3 \text { = Polesta } \quad 4=\mathrm{R} 1655 \quad 5=\mathrm{Fl} \text { hybrid }
$$

Based on the mean number of the two study seasons, the results revealed that variety Polesta harbored significantly the highest number of the spider mite (166.73 individuals/10 leaves), while breeding line R1655 received the least number (59.29 individuals/10 leaves). The rest cultivars showed variable levels of infestation. As for the white fly, French bean received significantly the highest number (11.98 insects/ 10 leaves) followed by Fl hybrid and Polesta with mean of 10.01 and 8.92 insects, respectively, while Pronco and R1655 harbored the lowest number (6.08 and 5.55 insects).

However, plant resistance to insects is generally derived from certain biochemical and /or the metabolism of insects influencing the relative degrees of damage caused by these insects ( Metcalf and Luckmann, 1975).

In respect to the susceptibility degree (SD) to the two pests, results in table (3) revealed that, the variety Polesta , French bean and breeding line FI hybrid appeared susceptible (S), as they exhibited the highest numbers of the two pests. The variety Pronco appeared as low resistant (LR), while the breeding line R1655 appeared as moderate resistant (MR). However, it is an important to point out herein that the pest mean numbers must refer to and / or agree with the resistance degree of variety or line (Hybrid). 
1292 EVALUATION OF CERTAIN KIDNEY BEAN, PHASEOLUS VULGARIS L. VARIETIES FOR THEIR INFESTATION WITH TETRANYCHUS CUCURBITACEARUM (SAYED) AND BEMISIA TABACI (GENN.) UNDER FIELD CONDITIONS OF KAFR EL-SHEIHK

Table 3. Mean number and susceptibility degrees(SD) of certain bean varieties and breeding lines to Tetranychus cucurbitacearum (Sayed) and Bemisia tabaci (Genn) during the two successive seasons of 2008 and 2009.

\begin{tabular}{|c|c|c|c|c|c|c|c|c|}
\hline \multirow{2}{*}{$\begin{array}{l}\text { Variety or } \\
\text { breeding line }\end{array}$} & \multicolumn{4}{|c|}{ T. cucurbitacearum } & \multicolumn{4}{|c|}{ B. tabaci } \\
\hline & 2008 & 2009 & Mean \pm SD* & SD & 2008 & 2009 & Mean \pm SD* & SD \\
\hline Pronco & $159.43 b$ & $58.69 c$ & $109.06 \pm 71.0 \mathrm{~d}$ & LR & $2.76 \mathrm{bc}$ & $9.39 c$ & $6.08 \pm 4.7 c$ & LR \\
\hline Frensh bean & $241.05 a$ & $44.46 d$ & $142.77 \pm 137.4 b$ & $S$ & $6.59 a$ & $17.36 a$ & $11.98 \pm 7.6 a$ & $\mathrm{~S}$ \\
\hline Polesta & $153.41 b$ & $180.04 a$ & $\mathrm{I} 66.73 \pm 18.8 \mathrm{a}$ & $\mathrm{S}$ & $2.20 \mathrm{c}$ & $15.64 a b$ & $8.92 \pm 9.5 b$ & $S$ \\
\hline FI hybrid & $154.76 \mathrm{~b}$ & $111.54 b$ & I33.15+30.6c & $\mathrm{S}$ & $5.70 a$ & $14.32 \mathrm{~b}$ & $10.01 \pm 6.1$ & $\mathrm{~S}$ \\
\hline RI655 & $105.55 \mathrm{c}$ & $33.00 \mathrm{e}$ & $69.28 \pm 51.3 \mathrm{e}$ & MR & $3.13 b$ & $7.96 \mathrm{c}$ & $5.55 \pm 3.4 \mathrm{e}$ & MR \\
\hline F-value & 200.61 & 309.28 & 160.88 & & 33.56 & 23.93 & 30.14 & \\
\hline
\end{tabular}

SD* = standard deviation

For each column, means followed by the same letter are not significantly different at $5 \%$ level of probability by Duncan Multiple Range Test (1955).

From the foregoing results, it could be concluded that the population of the spider mite was more abundant than whitefly during the two seasons. Also, French bean, Bolesta and FI hybrid appeared susceptible to the two pests, while pronco and R1655 appeared low infested and moderate resistant, respectively.

\section{REFERENCES}

1. Chiang, H. S. and N. S. Talekar. 1980. Identification of sources of resistance to the beanfly and two agromized flies in soybean and mungbean. J. Econ. Entomol. 73(2): 197-199.

2. Dent, D. 1991. Insect pest management. C. A. B. International Wallingford UK.604. PP.

3. Duncan, D. B. 1955. Multiple range and multiple f-tests. Biometrics $11: 1-42$.

4. Helaly, M. M, A.E. Ibrahim and M. R. A. Saleh. 1983. Fluctuation of population densities of Empoasca sp., Aphis craccivora Koch and Tetranychus arabicus Attiah attacking Cowpea plants Zagazig, Egypt. Bull. Ent., Soc.Egypt.

5. John, W. N. JR, S. Maria and M. Katherine. 1986. Toxicity of clorfentezine against the two spotted and carmine spider mite (Acari:Tetranychidae). J. Econ. Entomol., 79(2):479-483. 
6. Kumar, R. 1984. Insect pest control with special reference to African agriculture. Edward Arnold ,London.298pp.

7. Metcalf, R.L. and W.H. Luckmann. 1975. Introduction to insect pest management. John Wiley \& Sons, Inc. New York.587 pp.

8. Metwally, S. A. G. 1989. Ecological studies on some insect pests infesting certain legume crops in Qualubia governorate. Ph.D. Thesis, Fac. Agric., Cairo Univ.

9. Metwally, S. A. G. and M. M. A. Mahgoub. 1991. Susceptibility of some Cowpea varieties to Aphis craccivora Koch with special reference to Enzymes activities and reducing Sugar. Fourth Arab Congress of Plant Protection Cairo,I-5Dec.:153-157.

10. Pena Rojao, E. A., A. Pantoja and J. S. Beaver. 1992. Determination of the four genotype of bean (Phaseolm vulgaris L) and its effect on the insect Bemisia tabaci (Genn.) Reviota Colombiana de Entomologia, 18(2): 41. (C.F.Rev.Agric.Ent.) 82 (7):9846.

11. Wahba, M. L., S. A. Doss, F. S. Faris and M. K. Nakhla. 1986. Evaluation of some Phaseolus vulgris L.cultivars to infestation with aphids and mites. Agric. Res. .Rev., 64 (1):163-170. 


\title{
تقييم بعض أصناف و سلالات الفاصوليا للإصابة بالعنكبوت الأحمر العادي والأبابة

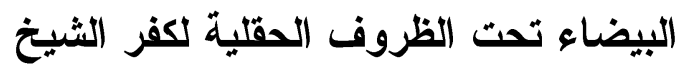

\author{
رفعت إبراهيم السيد معجوز سمير السيد السيد قاسم جيهان بدوي النجار

$$
\text { معرد بحوث وقابة النباتات - مركز البحوث الزراعية - الدقى - الجيزة }
$$

تم إجر اء تجارب حقلية بمزرعة محطة البحوث الزر اعية بسخا - كفر الثيخ لدراسة الكثافة

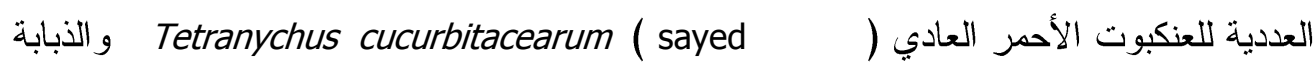

البيضاء Bemisia tabaci علي ثلاثة أصناف Polesta ,Pronco. French bean وسلالتين Fl hybrid

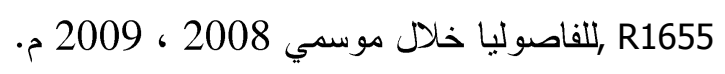

أوضحت النتائج أن أعلي تعداد للعنكبوت الأحمر كان في الأسبوع الثالث من شهر يوليو في

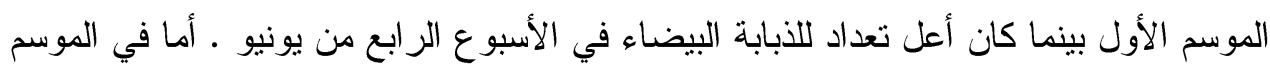

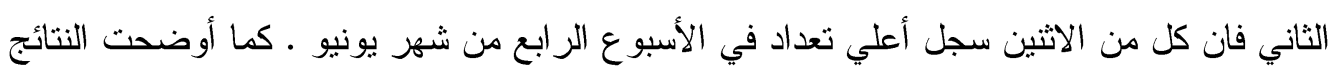

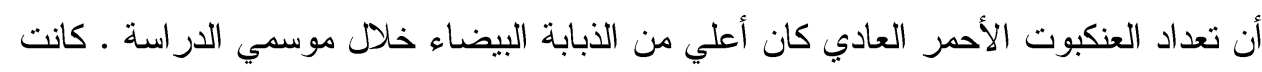

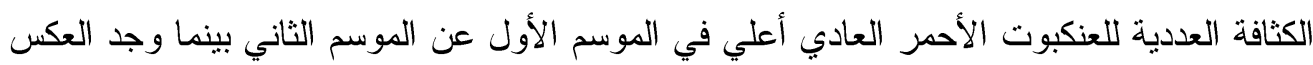
بالنسبة للذبابة البيضاء .

وبناء علي متوسط التعداد في الموسمين وجد أن صنف Polesta سجل معنويا أعلي تعداد

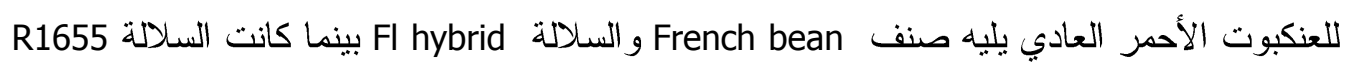
أقلهم إصابة - كما وجد أن أعلي إصابة بالذبابة البيضاء كانت علي الصنف French bean بينما

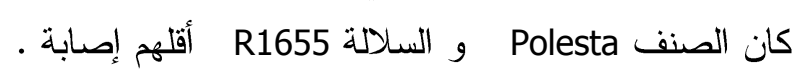

كما وجد من الدراسة أن درجة الحساسية للأصناف و السلالات المختبرة لكل من الآقتين أن

الصنف Polesta ، French bean و السلاسة Fl hybrid كانت حساسة للإصابة بهاتين الآفتين

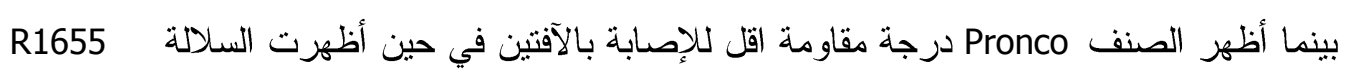
درجة مقاومة متوسطة . و هكذا فان هذه النتائج يجب أن تؤخذ في الاعتبار عند تصميم برامج الإدارة المتكاملة للآفات 